\title{
A full example of technical procedure to application of the Kansei Engineering
}

\author{
Lucelindo Dias Ferreira Junior ${ }^{a}$, Daniel Capaldo Amaral ${ }^{b}$ \\ Universidade Federal dos Vales do Jequitinhonha e Mucuri \\ bniversidade de São Paulo \\ *e-mails: lucelindo.ferreira@gmail.com; amaral@sc.usp.br
}

\begin{abstract}
Kansei Engineering is a method used to obtain customers impressions and generate final design solutions. There are real cases procedures and applications published that are superficially explained in most papers. The method is criticized for its limitation in generating innovative solutions. This paper presents a technical and operational procedure of Kansei engineering, which focuses in the creation of product concepts in order to support the project team in the search of innovative solutions rather than focus on obtaining a final solution. The procedure uses a combination of the quantification theory type I, triangular fuzzy numbers ranking, and genetic algorithms methods, to generate a population of solutions which serve as guidance about customers impressions to the project team, engineers or designers. The paper details the technical procedure, using a simple example, a design of a coffee mug, so that it can be easily reproduced and tested by other researchers and professionals.
\end{abstract}

Keywords: customer-oriented design, Kansei engineering, product design, triangular fuzzy number, quantification theory type I, genetic algorithm.

\section{Introduction}

Kansei engineering was developed in the 1970s by Mitsuo Nagamachi and has several meanings. The term Kansei can be understood as a semantic group that combines two words, sensitivity (kan) and sensibility (sei). According to Stappers, Harada and Lee (2002), Kansei is the Chinese word that implies sensitivity, sense, sensibility, feeling, aesthetics, emotion, affection, and intuition.

Nagamachi $(1995,2002,2004,2008)$ defines Kansei engineering, or affective engineering, as the technology to translate consumer Kansei into the domain of product design; that is, it converts the emotions and feelings that consumers have in relation to an artifact, or affective responses, into design specifications. Such a definition can be complemented by the definition formulated by Schütte $(2002,2005)$, who refers to Kansei engineering as a product development methodology to systematically explore and translate the emotions, impressions, and feelings of a large number of consumers and users with little specialization, into solutions and concrete parameters of design. In this process, mathematical, statistical, and heuristic methods, such as fuzzy theory (LIN; LAI; YEH, 2007), genetic algorithms (HSIAO; CHIU; LU, 2010), quantification theory type I (YANG; NAGAMACHI; LEE, 1999), rough set theory (ZHAI; KHOO; ZHONG, 2009), and neural networks (LAI et al., 2006), are used for building a Kansei engineering system. This system is capable of generating optimal probable configurations of products that are best suited for the given linguistic variables using relational rules based on a survey conducted with consumers, which includes the identification of verbal impressions (linguistic variables) regarding specific product types.

Some authors have proposed different Kansei engineering systems, software, and algorithms capable of establishing a relation between consumers and/or user impressions and technical parameters of design, using, for instance, genetic algorithms (HSIAO; CHIU; LU, 2010) fuzzy theory (LIN; LAI; YEH, 2007), rough set theory (ZHAI; KHOO; ZHONG, 2009), neural networks (LAI et al., 2006; ISHIHARA; NAGAMACHI; ISHIHARA, 1995), quantification type I (CHEN; CHUANG, 2008). They present different levels of sophistication, from systems that only have the correlation between words and characteristics to those referenced in the theory as Kansei engineering systems type II, which result in a product concept that would be optimal from the client's viewpoint (NAGAMACHI; LOKMAN, 2011). There are several reports of applications in real cases, e.g. design of rocker switches (SCHÜTTE; EKLUND, 2005), mobile phone (LAI et al., 2006), car (LAI; CHANG; 
CHANG, 2005), packaging and appearance of chocolate snacks (SCHÜTTE, 2013), and traditional craft products (HUYNH; YAN; NAKAMORI, 2010). A common criticism is that Kansei engineering does not allow for the creation of innovative products (SCHÜTTE et al., 2008). The criticism is that this method operates with past data of the existing products and is limited to the information that the consumer already has. Therefore, the result cannot be innovative.

Among theorists who work with projects involving innovative products, the common criticism is that consumers in general do not know and therefore are not capable of expressing their actual needs clearly and reliably (VON HIPPEL, 1986; THOMKE; VON HIPPEL, 2002). Bonner and Porter (2002) state that consumers may have difficulty in cooperating to explore and create new ideas, predominantly for innovative products. Lettl (2007) presents a more detailed idea by considering that there are two main barriers that make it difficult for consumers to cooperate in projects with radical innovations; these barriers are the cognitive and motivational limitations. The first barrier causes the following problems, according to a review conducted by Lettl (2007): (1) consumers find it difficult to contribute to the creation of ideas because they are restricted to the context of general use; (2) consumers find it difficult to assess concepts and prototypes that are not equivalent to an existing product; and (3) consumers are not capable of providing useful information when the solution requires the use of relatively high technological complexity.

In order to overcome such barriers, as well as limitations of Kansei engineering with respect to the creation of innovative products, a distinct approach can be used. Instead of a methodology used for creating product concepts and designs, Kansei engineering can be used for supporting the project team in the creation of ideas by providing consumer impression information that can assist in this process. When addressing the problem this way, the challenge is to create a Kansei engineering system capable of providing alternative concepts for the project team as part of the product development process.

In this article, quantification theory type I (NAGAMACHI, 2011), triangular fuzzy numbers (TFN), and genetic algorithms have been combined to create a Kansei engineering system for providing alternative product concepts that express consumer impressions and work as a link between consumers and project teams. In this paper, we will qualitatively describe the nine phases of the proposed Kansei engineering system and justify the nonconsensual procedures. We will also provide a quantitative description of each phase by introducing adequate ratings as well as mathematical and heuristic models.

Quantification theory type I (NAGAMACHI, 2011) is used for determining the degree of importance of each characteristic of the product being considered with respect to each linguistic variable. TFNs are applied to the classification of linguistic variables in the order of importance. Further, the use of a genetic algorithm is suggested in order to obtain product configurations that maximize the use of characteristics with relatively high scores. This composition of methods is different from the methods found in the literature and has certain advantages. The first advantage is the choice of quantification theory type I, which aims at estimating the relation among linguistic variables and consumer impression indicators, and the second advantage is the product characteristics that have the benefit of enabling the assessment of new product configurations without the need for a new interaction with the consumers. The choice of importance classification of linguistic variables using TFNs has the benefit of enabling the quantitative manipulation of inaccurate subjective information from consumers that are represented with linguistic variables. Finally, a genetic algorithms is used as it is different from the other traditional methods of search, such as gradient (hill climbing), because of its capability of performing the search in different solution space areas; i.e., in the event of using a Kansei engineering system, the use of a genetic algorithm has the advantage of not restricting solutions and product concepts to optimal locations.

Thus, this new composition of methods has the advantage of enabling the creation of new product concepts in a predictable manner on the basis of previous information obtained from consumers by mitigating the inaccuracies of such information and considering a relatively large field of optimal solutions.

To illustrate the use of the proposed Kansei engineering system, the development of a coffee mug is provided as an example. The example was specifically chosen for its simplicity, which facilitates an understanding of the technical procedure for application and testing in real cases, that is not the focus of this paper.

\section{Kansei Engineering System model (KES model)}

The phases of the proposed Kansei engineering system are described as an operational and customized application of the theoretical model developed by Schütte (2002). The proposed model is comprised of nine phases as shown in Figure 1. An explanation of the phases is provided below in order to aid the comprehension of the operating process of the proposed Kansei engineering system.

Phase 1. Choice of domain. In this phase, the type of product and target audience, consumers and users, of the product being developed are determined; i.e., the product domain is characterized. In order to characterize the type of prospective product, the most important traces of such a product can be designed by using, possibly, a combination of abstract and intangible characteristics, representing samples of existing products, concepts, products, or solution 


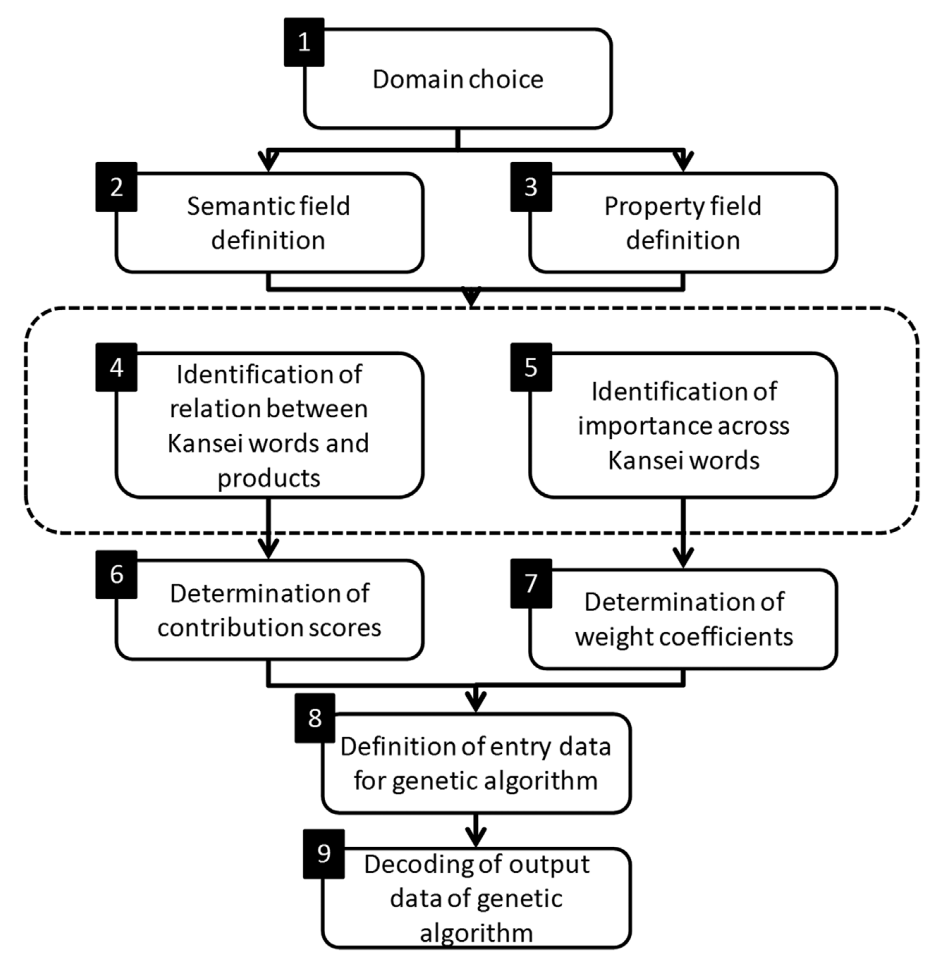

Figure 1. Nine-phase model of the proposed Kansei engineering system. Source: Adapted from Schütte (2002).

principles, for instance. All the information gathered in this phase will form the Kansei domain of the product.

Phase 2. Semantic field definition. In this phase, Kansei words (linguistic variables) are collected; these are expressions that describe the previously established domain. These words are usually adjectives and qualify the broadest and the most reliable potential type of product characterized in the domain. According to Nagamachi and Lokman (2011), a large number of words must be collected. It is recommended to collect between 600 and 800 words from several sources of research, such as magazines, books in the field, manuals, and interviews with specialists, consumers, users, and people included in the product project team. After collecting such Kansei words, the number of words must be reduced using a ranking process. The purpose is to identify the most adequate and common words used for representing the domain of the characterized product. Schütte (2002) suggests two modes of Kansei word reduction. The first possibility refers to the reduction of words by using statistical tools, such as a cluster or factor analysis, after a characterization of words using semantic differential scales. Semantic differential scales (OSGOOD; SUCI; TANNENBAUM, 1957) are linear scales that have deliberately contrary statements in their extremities. The data from this characterization, done by the consumer, for example, are processed statistically to indicate the most relevant Kansei words.
The second mode of reducing the collected Kansei words is by manually classifying words into categories. This activity can be performed by specialists and/or consumers in the focus group sessions. Schütte et al. (2008) suggest that the words be written in individual cards so that one can have an idea of the groups formed in order to better process words across categories, when in team activities. At the end, there will be high-level words with a more generic meaning characterizing groups of words, which will be referred to as Kansei words. The quality of the result of this activity will be directly linked to the level of experience of the people involved. Delin et al. (2007) collaborates interestingly in this sense, with the development of a structured process to collect, screen, and select Kansei words using computational tools for the semantic analysis, assisted by linguistic specialists. The intention of the authors is to make the results more robust, allow for replication, and reduce the use of excessively ambiguous words.

There are other ways to obtain consumer Kansei. According to Ishihara (2011), the following are methods used for capturing Kansei on the basis of psychophysiological responses, such as electromyography (EMG), electroencephalography (EEG), electrocardiogram (ECG), to capture eye movement, analyze facial expressions, etc. These methods, which are still in the consultation phase in scientific literature, have potential use in Kansei engineering systems aimed at obtaining more reliable 
information regarding consumer impressions, feelings, and emotions.

Phase 3. Property field definition. In this phase, product characteristics that can more clearly describe the type of prospective product characterized in the domain are identified and collected. The selection of product characteristics will result in the construction of a database with target product styles. According to Schütte et al. (2004), these product characteristics may be found in technical documents, potential competitor products, magazines, specialized literature, product manuals, previous Kansei studies, etc. The product characteristics can also be obtained from suggestions from the project team and/or consumers and users. They can, for example, present ideas of existing or non-existing desirable characteristics.

Subsequently, the collected characteristics must be sorted by type using a ranking system similar to that used in the classification of Kansei words. Therefore, the collected properties can be refined similarly to how Kansei words were refined. It is also possible to determine the degree of relevance of each type of characteristic with respect to all the collected characteristics, following the perspective of consumers and specialists. This activity can be performed with focus groups, for example, and the results can be presented using a Pareto diagram (SCHÜTTE et al., 2004) to facilitate the selection of the most relevant characteristics that will be focused on during the development of the new product. It is interesting to mention that the participation of leading users and consumers may simplify the refinement and reduction activity of the collected product characteristics, thus maintaining work reliability when not opting for statistical analysis methods. Interesting proposals for the identification of product properties are suggested by Schütte (2006) and Barnes and Lilford (2009). Finally, products (product-synthesis) that represent and synthesize the configurations comprised of identified characteristic combinations are selected by considering the list of product characteristics classified as the most relevant. Products-synthesis can be built for research, such as mockups, prototypes, and three-dimensional models, or they can be existing products. It is important to refer that many difficulties are in the property field definition Schütte et al. (2008), because is not sufficiently clear in the literature about Kansei engineering how to select the properties of an specific product type, and how obtain a group of product-synthesis samples that represents the properties selected in an optimal manner, especially if we pretend to use existent products to represent this domain. We opting by use Morphological Analysis in the property field definition, based on the work of Hsiao, Chiu and $\mathrm{Lu}$ (2010), aiming identify initial properties of the target product and generate possible configurations of product-synthesis, considering existent products in the market, selected based on recommendations proposed by Nagamachi and Lokman (2011) for the selection of product samples.

Phase 4. Relation identification between Kansei words and products-synthesis. In this phase, the Kansei words and linguistic variables are linked to product characteristics. Consumers and users, previously defined in the first step, are requested to assess (through a survey), using numerical scales, the adherence of Kansei words to the products-synthesis, i.e., the extent to which the products representing the domain are correlated to impressions, feelings, and emotions indicated on each nominal expression. The scale used for assessing the products-synthesis may be the semantic differential scale (OSGOOD; SUCI; TANNENBAUM, 1957) mentioned previously; and its extremities (poles) would indicate the complete absence or presence of the referred quality in each Kansei word (Figure 2).

Phase 5. Importance identification among Kansei words. In this phase, which occurs concurrently with the relation identification phase between Kansei words and products-synthesis, consumers and users are requested to assess the relative degree of importance of linguistic variables using numerical scales.

Phase 6. Determination of contribution scores. In this phase, the data obtained in Phase 4 are compiled and processed using statistical methods. Nagamachi (2004) mentions the use of the cluster and factor analysis methods in addition to the quantification theory types I, II, III, and IV presented by Hayashi (1974). Schütte et al. (2008) also mention the use of regression analysis. In this study, we use quantification theory type I. In this case, at the end of the statistical processing, it is possible to obtain the degree of association between each product characteristic and Kansei word, which will provide support for the construction of a prediction model.

Phase 7. Determination of weight coefficients. In this phase, the degree of importance assessment of a consolidation of Kansei words, performed by consumers and users in Phase 5, as well as the determination of the

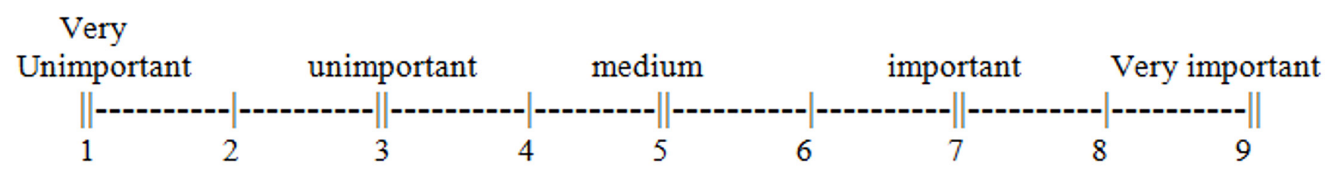

Figure 2. Nine-point importance scale. Source: Chan, Kao and Wu (1999). 
weight coefficients of linguistic variables take place with the use of the TFN theory, following what is performed by Chan, Kao and Wu (1999).

Phase 8. Definition of entry data and implementation of genetic algorithm. In this phase, the structure of the chromosome, the number of genetic variables, the number of creations, the number of crossover points, and the mutation probability to initiate the optimization process using a specific genetic algorithm are defined with a predefined assessment function. The genetic algorithm, at the end of the optimization process, will indicate the chromosome configurations that will maximize the assessment value.

Phase 9. Decoding of output data of genetic algorithm. In this phase, the chromosomes generated after specific genetic algorithm optimization cycles are decoded. The chromosomes with the highest rating will be translated in terms of product configurations.

In the next section, the mathematical operational structure used for carrying out the phases of the model proposed above will be presented.

\section{Mathematical structure of the KES model}

Considering the nine-phase model explained above, we can describe a Kansei engineering system in mathematical terms according to the following description:

Phase 1. Definition of type of product and target audience, consumers and users, and product in development.

Phase 2. Collection of verbal impressions from potential users and consumers, identified as $\mathrm{Ci}$, with respect to the characteristics of the type of product characterized in the product domain, from which a group of words identified as $\mathrm{K} 1, \ldots, \mathrm{Kn}$ is selected. This group of linguistic variables is ranked using the Kawakita Jiro (KJ) Method (affinity diagram), in order to select the most representative words.

Phase 3. Construction of a database with target product styles through segmentation in a proper set of items and categories. The items, identified as I1,.., IR, are defined as design elements, or parts that form a prototype, and are established through the procedure used by Hsiao, Chiu and $\mathrm{Lu}$ (2010). Each item Is has a set of categories, given by $\mathrm{c}_{s 1}, \ldots, \mathrm{c}_{s k_{\circ}}$, for $\mathrm{s}=1,2, \ldots, \mathrm{R}$, which indicate variety. The link item-category is referred to as a product characteristic. On the basis of the proposed segmentation, compositions with the goal of creating representative products (product-synthesis) of the identified items/categories are made.

Phase 4. Establishment of relation between productssynthesis $\mathrm{P} 1, \ldots, \mathrm{Pm}$ and each linguistic variable Ki by collecting information from a sample of target users and consumers, identified as $\mathrm{C} 1, \ldots, \mathrm{Cw}$, using a nine-point scale. The assessment of each products-synthesis, in terms of a given linguistic variable, is expressed verbally using qualifiers such as "unimportant" and "very important" that are linked to a numerical sequence from 1 to 9 , as shown by Chan, Kao and Wu (1999).

Phase 5. Each Kansei word Ki is assessed, by target users and consumers, with respect to the relative degree of importance for each type of product undergoing the analysis, using a nine-point scale.

Phase 6. The degree of contribution for each product category, for each linguistic variable, is obtained through the average assessment of the adherence of the products-synthesis to each selected Kansei word. In such a case, a group of consumers $\mathrm{C} 1, \ldots, \mathrm{Cw}$ must assess the adherence of each products-synthesis $\mathrm{Pi}$ with respect to linguistic variables $\mathrm{K} 1$ using a nine-point scale. Then, the assessment averages are determined in relation to consumers. These average values, processed as elements of an objective variable are linked to a nominal explanatory variable associated with the categories described for the type of product being considered using quantification theory type I. An implementation of the quantification theory type I is possible with the QT1 program proposed by Professor Shigenobu Aoki, suggested and exemplified in Nagamachi (2011). This program is applicable in the R software.

\subsection{Quantification theory type I}

Quantification theory type I (QTI), developed by Hayashi (1952, 1954), and adapted by Nagamachi (2011) aimed at the development of a Kansei engineering system, consists of a generalization of the multiple linear regression analysis method. In fact, QTI amplifies the class of variables processed by the multiple linear regression analysis by working with ordinal objective variables and nominal explanatory variables. In Kansei engineering applications, each variation (category) in a product item is associated with a nominal explanatory variable and applied to the multiple linear regression analysis.

Following the formal structure proposed by Hayashi (1954), consider $y_{\lambda}$ an ordinal objective variable, representative of the average assessment of the degree of importance of each linguistic variable $\mathrm{K}_{\mathrm{i}}$ in relation to the $\lambda$-th products-synthesis, where $\lambda=1,2, \ldots, \mathrm{m}$. Assuming, as was explained previously, that each item $\mathrm{I}_{\mathrm{s}}$ has a set of associated categories $\left\{\mathrm{c}_{\mathrm{s} 1}, \mathrm{c}_{\mathrm{s} 2}, \ldots, \mathrm{c}_{\mathrm{sks}}\right\}$, where $\mathrm{s}=1,2, \ldots, \mathrm{R}$. $\mathrm{E}$, considering that categories $\mathrm{c}_{\mathrm{sj}}$ are related to an explanatory variable dummy $\mathrm{x}_{\mathrm{s} j}$, is indicative of the presence or absence of the sj characteristic in products-synthesis $\lambda$, and a table with the configuration standards for $\mathrm{m}$ products-synthesis and its respective objective variables can be built (Table 1)

Based on the values presented in Table 1, an estimate model of the objective variable can be established from product configuration standards. The method of devising the relation between objective variables and explanatory variables consists of writing the objective variable as a linear combination of dummy variables, as proposed by 
Table 1. Objective variables and product configuration standards.

\begin{tabular}{|c|c|c|c|c|c|c|c|c|c|c|c|c|}
\hline \multirow[t]{2}{*}{ Item } & \multicolumn{4}{|c|}{$\mathrm{I}_{1}$} & \multicolumn{4}{|c|}{$\mathrm{I}_{2}$} & \multirow{2}{*}{$\begin{array}{l}\cdots \\
\cdots\end{array}$} & \multicolumn{3}{|c|}{$I_{R}$} \\
\hline & $\mathrm{c}_{11}$ & $\mathrm{c}_{12}$ & $\ldots$ & $\mathrm{c}_{1 \mathrm{k}_{1}}$ & $\mathrm{c}_{21}$ & $c_{22}$ & $\ldots$ & $\mathrm{c}_{2 \mathrm{k}_{2}}$ & & $\mathrm{c}_{\mathrm{R} 1}$ & $\ldots$ & $\mathrm{c}_{\mathrm{Rk}_{\mathrm{R}}}$ \\
\hline $\mathrm{y}_{1}$ & $\mathrm{X}_{111}$ & $\mathrm{x}_{121}$ & $\ldots$ & $\mathrm{x}_{1 \mathrm{k}_{1} 1}$ & $\mathrm{x}_{211}$ & $\mathrm{x}_{221}$ & $\ldots$ & $\mathrm{x}_{2 \mathrm{k}_{2} 1}$ & $\ldots$ & $\mathrm{X}_{\mathrm{R} 11}$ & $\ldots$ & $\mathrm{x}_{\mathrm{Rk}_{\mathrm{R}} 1}$ \\
\hline $\mathrm{y}_{2}$ & $\mathrm{x}_{112}$ & $\mathrm{X}_{122}$ & $\ldots$ & $\mathrm{X}_{1 \mathrm{k}_{1} 2}$ & $\mathrm{x}_{212}$ & $\mathrm{x}_{222}$ & $\cdots$ & $\mathrm{x}_{2 \mathrm{k}_{2} 2}$ & $\ldots$ & $\mathrm{x}_{\mathrm{R} 12}$ & $\ldots$ & $\mathrm{x}_{\mathrm{Rk}_{\mathrm{R}} 2}$ \\
\hline$\vdots$ & $\vdots$ & $\vdots$ & $\vdots$ & $\vdots$ & $\vdots$ & $\vdots$ & $\vdots$ & $\vdots$ & $\vdots$ & $\vdots$ & $\vdots$ & $\vdots$ \\
\hline $\mathrm{y}_{\mathrm{j}}$ & $\mathrm{x}_{11 \mathrm{j}}$ & $\mathrm{X}_{12 \mathrm{j}}$ & $\ldots$ & $\mathrm{x}_{1 \mathrm{k}_{\mathrm{l}} \mathrm{j}}$ & $\mathrm{X}_{21 \mathrm{j}}$ & $x_{22 j}$ & $\ldots$ & $\mathrm{x}_{2 \mathrm{k}_{2} \mathrm{j}}$ & $\ldots$ & $\mathrm{X}_{\mathrm{R} 1 \mathrm{j}}$ & $\ldots$ & $\mathrm{X}_{\mathrm{Rk}_{\mathrm{R}} \mathrm{j}}$ \\
\hline$\vdots$ & $\vdots$ & $\vdots$ & $\vdots$ & $\vdots$ & $\vdots$ & $\vdots$ & $\vdots$ & $\vdots$ & $\vdots$ & $\vdots$ & $\vdots$ & $\vdots$ \\
\hline $\mathrm{y}_{\mathrm{m}}$ & $\mathrm{x}_{11 \mathrm{~m}}$ & $\mathrm{x}_{12 \mathrm{~m}}$ & $\ldots$ & $\mathrm{x}_{1 \mathrm{k}_{1} \mathrm{~m}}$ & $\mathrm{x}_{21 \mathrm{~m}}$ & $\mathrm{x}_{22 \mathrm{~m}}$ & $\ldots$ & $\mathrm{x}_{2 \mathrm{k}_{2} \mathrm{~m}}$ & $\ldots$ & $\mathrm{X}_{\mathrm{R} 1 \mathrm{~m}}$ & $\ldots$ & $\mathrm{X}_{\mathrm{Rk}_{\mathrm{R}} \mathrm{m}}$ \\
\hline
\end{tabular}

Nagamachi (2011). Thus, for a given products-synthesis $\lambda$, we have:

$$
\mathrm{y}_{\lambda}=\sum_{\mathrm{s}=1}^{\mathrm{R}} \sum_{\mathrm{j}=1}^{\mathrm{k}_{\mathrm{s}}} \mathrm{a}_{\mathrm{sj}} \mathrm{x}_{\mathrm{sj} \lambda}+\varepsilon_{\lambda}
$$

where $\mathrm{a}_{\mathrm{sj}}$ is the contribution score of the category and $\varepsilon_{\lambda}$ is the residual random variable.

Considering the $\mathrm{m}$ products-synthesis, the model has the following format, in matrix notation:

$$
\left[\begin{array}{c} 
\\
\mathrm{y}_{1} \\
\mathrm{y}_{2} \\
\vdots \\
\mathrm{y}_{\mathrm{m}}
\end{array}\right]=\left[\begin{array}{cccc}
\mathrm{x}_{111} & \mathrm{x}_{121} & \ldots & \mathrm{x}_{\mathrm{Rk}_{\mathrm{R}} 1} \\
\mathrm{x}_{112} & \mathrm{x}_{122} & \ldots & \mathrm{x}_{\mathrm{Rk}_{\mathrm{R}} 2} \\
\vdots & \vdots & \ddots & \vdots \\
\mathrm{x}_{11 \mathrm{~m}} & \mathrm{x}_{12 \mathrm{~m}} & \ldots & \mathrm{x}_{\mathrm{Rk}_{\mathrm{R}} \mathrm{m}}
\end{array}\right]\left[\begin{array}{c} 
\\
\mathrm{a}_{11} \\
\mathrm{a}_{12} \\
\vdots \\
\mathrm{a}_{\mathrm{Rk}_{\mathrm{R}}}
\end{array}\right]+\left[\begin{array}{c} 
\\
\varepsilon_{1} \\
\varepsilon_{2} \\
\vdots \\
\varepsilon_{\mathrm{m}}
\end{array}\right] \Leftrightarrow Y=X \cdot a+\boldsymbol{\varepsilon}
$$

where the error matrix assumes the following properties Johnson and Wichern (2007):

$$
\begin{aligned}
& \text { I. } \mathrm{E}(\boldsymbol{\varepsilon})=0 \\
& \text { II. } \operatorname{cov}(\boldsymbol{\varepsilon})=\mathrm{E}\left(\boldsymbol{\varepsilon} \boldsymbol{\varepsilon}^{\prime}\right)=\sigma^{2} \mathbf{I}
\end{aligned}
$$

For the determination of the $\mathrm{a}_{\mathrm{sj}}$ parameters, it is necessary to adjust the model, given by the Equation 1, to the collected $\mathrm{y}_{\lambda}$ data that correspond to the known values $\mathrm{x}_{\mathrm{sj} \lambda}$. The adjustment is made using the least square criteria.

Phase 7. The consolidation of the individual assessments of the relative degree of importance attributed to linguistic variables and the determination of weight coefficients for each variable are performed using representations of TFNs, aiming to consider the vagueness of the customers' input.

\subsection{Triangular fuzzy numbers}

A TFN is written as $\mathrm{K}=(\mathrm{a}, \mathrm{b}, \mathrm{c})$, where a $\leq \mathrm{b} \leq \mathrm{c}$ and represents the concept given by the statement "K = approximately b", where the degree of approximation is established by the membership function:

$$
\mu_{\mathrm{k}}(x)=\left\{\begin{array}{lc}
0 & x \leq a \text { or } x \geq c \\
(x-a) /(b-a) & a \leq x \leq b \\
(c-x) /(c-b) & b \leq x \leq c
\end{array}\right\}
$$

It can be verified from Expression 4 that the functional values of $\mu_{\mathrm{k}}$ only admit values in the closed interval $[0,1]$.

In the context of the consumer assessment representation, Chan, Kao and Wu (1999) suggest the use of a nine-point scale, which can be represented using TFNs in order to consider the inaccuracy of subjective assessments. Consequently, each value in the scale will have the following representation:

$$
\begin{aligned}
& 1=[1,1,2] \\
& 2=[1,2,3] \\
& 3=[2,3,4] \\
& 4=[3,4,5] \\
& 5=[4,5,6] \\
& 6=[5,6,7] \\
& 7=[6,7,8] \\
& 8=[7,8,9] \\
& 9=[8,9,9]
\end{aligned}
$$

These TFNs can be classified using the criteria given by Chan, Kao and $\mathrm{Wu}$ (1999). Assume any two TFNs written as $\mathrm{K}_{1}=\left(\mathrm{a}_{1}, \mathrm{~b}_{1}, \mathrm{c}_{1}\right)$ and $\mathrm{K}_{2}=\left(\mathrm{a}_{2}, \mathrm{~b}_{2}, \mathrm{c}_{2}\right)$; then

I. If $a_{2} \geq a_{1}, b_{2} \geq b_{1}, c_{2} \geq c_{1}$, and at least one inequality is maintained, then $\mathrm{K}_{2} \succ \mathrm{K}_{1}$, where symbol $\succ$ means "is more important than."

II. If $\mathrm{a}_{2}=\mathrm{a}_{1}, \mathrm{~b}_{2}=\mathrm{b}_{1}$, and $\mathrm{c}_{2}=\mathrm{c}_{1}$, then $\mathrm{K}_{2}=\mathrm{K}_{1}$.

III. If $\mathrm{a}_{2} \leq \mathrm{a}_{1}, \mathrm{~b}_{2} \leq \mathrm{b}_{1}, \mathrm{c}_{2} \leq \mathrm{c}_{1}$, and at least one inequality is maintained, then $\mathrm{K}_{1} \succ \mathrm{K}_{2}$.

Additionally, TFNs admit their own operational properties. Among them, we can underscore the properties of scalar multiplication and addition for use in the classification (DUBOIS; PRADE, 1980; CHAN; KAO; WU, 1999). 
I. Addition: $\mathrm{K}_{1}+\mathrm{K}_{2}=\left(\mathrm{a}_{1}+\mathrm{a}_{2}, \mathrm{~b}_{1}+\mathrm{b}_{2}, \mathrm{c}_{1}+\mathrm{c}_{2}\right)$

II. Scalar multiplication: $\propto \mathrm{K}_{1}=\left(\propto \mathrm{a}_{1}, \propto \mathrm{b}_{1}, \propto \mathrm{c}_{1}\right), \propto>0$

By applying the concepts and operational rules discussed above, we can use the representation of TFNs to obtain the representative weight coefficients of the degree of importance of Kansei words in relation to the product type determined. In particular, Kansei words are assessed by potential consumers and/or users with respect to the relative degree of importance using a nine-point scale. These assessments are then converted to TFNs. Then, the average, in relation to consumers, of the nine-point scale assessments and TFNs derived from these assessments is taken. The average values $\mathrm{K}_{1}$ to $\mathrm{K}_{n}$ in the TFNs are standardized to allow a comparison across these weight coefficients. Coefficients with a relatively high value for each linguistic variable are selected to integrate the weight component factor of Kansei words.

Phase 8. Entry data for the genetic algorithm, such as chromosome structure, number of genetic variables, number of creations, number of crossover points, and mutation probability are defined, and the optimization process is implemented with the use of a specific genetic algorithm. An implementation of the logical for the genetic algorithms may be made using the MATLAB tool, as used by Hsiao, Chiu and $\mathrm{Lu}$ (2010).

\subsection{Genetic algorithms}

The theory of genetic algorithms, established in the seminal work of Holland (1992), consists of a set of heuristic techniques for an overall optimization based on the processes of genetics and natural selection. It consists of directed random search systems that explore historic information to find relatively high aptitude points.

According to Gen and Cheng (1997), genetic algorithms can be structured with the following steps: encoding of problem solutions and chromosomes, construction of the initial population, definition of the assessment value, obtaining of optimal chromosomes, and decoding of the optimal chromosome.

The first step consists of defining the chromosomes, which consist of a chain of binary values, in which information regarding the presence (1) or absence (0) of a given characteristic is contained. In the second step, the population is initiated by randomly creating a pre-established number of individuals or chromosomes in order to create a satisfactory distribution of solutions in the search space. In the third step, the assessment values of the chromosomes are determined for a given creation in order to enable the identification and selection of the most suitable chromosome. To calculate the assessment values, it is necessary to previously define a function. In the third step, the criteria for the creation of new chromosomes, such as crossover and mutation, are applied by favoring those best assessed by the assessment function. In the third step, the chromosomes are decoded so that the solutions can be assessed and filtered according to user needs.

Genetic algorithms, from the perspective of Kansei engineering, have been used for creating new product configurations by utilizing assessment functions that maximize the perceived anticipated quality of the product on the basis of information previously collected from consumers regarding the sample of products in the same morphological structure.

For the proposed Kansei engineering system, after obtaining the contribution scores for each category and the weight coefficients for the Kansei words, we can obtain product configurations that maximize the use of characteristics with relatively high scores through a genetic algorithm. In such a case, it is necessary to define the assessment function of the chromosomes created by the genetic algorithm.

The assessment function makes use of the matrix comprised of the contribution score vectors, the weight coefficient vectors attributed to the Kansei words, and the matrix with the binary representation (chromosomes) of the products, where the presence of a given characteristic is indicated by 1 and the absence is indicated by 0 . The two first matrices are determined by the procedures presented in Phases 6 and 7; however, the matrix with the chromosomes depends on the genetic operations executed by the software based on the genetic algorithm, which is created after each evolutionary cycle. In general, the chromosome matrix can be represented as follows:

$$
G=\left[\begin{array}{ccccccc}
G_{111} & \cdots & G_{11 k_{1}} & \cdots & G_{1 R 1} & \cdots & G_{1 R k_{R}} \\
G_{211} & \cdots & G_{21 k_{1}} & \cdots & G_{2 R 1} & \cdots & G_{2 R k_{R}} \\
\vdots & \ddots & \vdots & \ddots & \vdots & \ddots & \vdots \\
G_{m 11} & \cdots & G_{m 1 k_{1}} & \cdots & G_{m R 1} & \cdots & G_{m R k_{R}}
\end{array}\right]_{m \times K}
$$

where the first index indicates the number of the chromosome (that is, the products-synthesis); the second, the item; and the third, the category. Finally, the function for assessing the chromosomes is expressed as follows:

$$
\mathrm{f}_{m \times 1}=\mathrm{G}_{m \times K} \mathrm{~A}_{K \times n} \mathrm{w}_{n \times 1}
$$

for $\mathbf{A}=\left[\begin{array}{llllll}\mathbf{a}_{1} & \mathbf{a}_{2} & \cdots & \mathbf{a}_{\mathrm{i}} & \cdots & \mathbf{a}_{\mathbf{n}}\end{array}\right]$, where $\mathbf{a}_{\mathrm{i}}$ represents the contribution scores of each characteristic in relation to the Kansei word $\mathrm{K}_{\mathrm{i}}$ obtained in Phase 6. The $\mathbf{w}$ vector contains the weight coefficients $\mathrm{w}_{\mathrm{i}}$ for each linguistic variable determined in Phase 7.

The individual assessment of a products-synthesis created by the genetic algorithm $\left(\tilde{\mathrm{P}}_{\mathrm{k}}\right)$ is given by the relation:

$$
\mathrm{f}_{\tilde{\mathrm{P}}_{\mathrm{k}}}=\sum_{\mathrm{i}=1}^{\mathrm{n}} \mathrm{w}_{\mathrm{i}} \sum_{\mathrm{s}=1}^{\mathrm{R}} \sum_{\mathrm{j}=1}^{\mathrm{k}_{\mathrm{s}}} \mathrm{G}_{\mathrm{ksj}} \mathrm{a}_{\mathrm{sji}}
$$


The described function assesses the chromosomes created in the genetic algorithm and allows for the classification of the most suitable ones during the evolutionary cycles.

Phase 9. Chromosomes with a better assessment, originated at the end of the evolutionary cycles, are decoded. Considering the chromosomes with the best assessment in Phase 8 , we convert the binary numbers, $\mathrm{x}_{\mathrm{s} j \lambda}$, which represent the absence or presence of a given category, into a schematic representation through the database of the target product styles.

\section{Illustrative example}

In the following paragraphs, a step-by-step application of the KES model will be discussed according to the concepts and calculations described in Sections 2 and 3. As the main objective of the example is to illustrate the operational procedures, we opting to present a design of a coffee mug. This example is sufficient to demonstrate the operation of the procedure and the feasibility of the algorithms and technical solution conceived. The simplicity also facilitates the use of the procedure by researchers and practitioners, a first step to test in real conditions. We exposed a mathematical structure of the KES model in a generalizable way to permit extend and amplify for many possibilities of applications, considering different types of products, specially manufactured products.

Phase 1. To illustrate the application of the KES model, we chose to develop a coffee mug that meets the needs of graduate students who are at the end of their dissertation, at a renowned educational institution; this is a time when the graduate students tend to consume more coffee than usual.

Phase 2. Based on the delimitation conducted in the previous phase, a representative sample of the existing student population in the intended niche is defined, and the student population is then requested to complete a questionnaire so that we can obtain preferences, expectations, and impressions regarding the desired coffee mug. For illustrative purposes, imagine 10 students are selected for interviews, $\mathrm{C}_{1}$ to $\mathrm{C}_{10}$. Thereby, and based on other sources of research, such as magazines, television advertisements, and dictionaries, a large number of Kansei words are collected through ranking by using the KJ method and reduced to 6 high-level representative words, $\mathrm{K}_{1}$ to $\mathrm{K}_{6}$, which are presented in Table 2.

Phase 3. For the design of the property field, items that must initially form a generic coffee mug are identified. The target product is distinguished using four items: (1) body, (2) base, (3) top, and (4) handle. This item distribution is presented in Table 3.

The items identified are then transformed into categories as shown in Table 4.

After defining the items and categories for the target coffee mug, mugs representing variations across the categories and items presented in Table 4 are selected. These mug variations are obtained considering the recommendations of Nagamachi and Lokman (2011) who have established the following: (a) a product in the selection cannot have more than one category for the same item; (b) there cannot be products with equal categories for all items simultaneously; and (c) there must be at least two selected product units in the same category for a given item. Therefore, 25 coffee mug configurations are selected, $\mathrm{P}_{1}$ to $\mathrm{P}_{25}$, shown in Table 5, in which each product has a possible combination of the items and categories shown in Table 4.

Phase 4. In order to identify the relation between Kansei words and products-synthesis, a structured questionnaire is built so that the participants, $C_{1}$ to $C_{10}$, can attribute a value from 1 to 9 to each products-synthesis described in the previous phase. This score will indicate the degree of adherence of each Kansei word to the characteristics of the selected coffee mug. In Table 6, an excerpt of the values attributed to the products by the consumers is presented, $\mathrm{P}_{1}$ to $\mathrm{P}_{25}$, pertaining to the words "pleasant aesthetics" $\left(\mathrm{K}_{1}\right)$ and "ergonomic" $\left(\mathrm{K}_{2}\right)$.

Table 2. List of Kansei words selected for the desired coffee mug.

\begin{tabular}{|c|c|}
\hline $\mathrm{K}_{1}$ & Pleasant aesthetics \\
\hline $\mathrm{K}_{2}$ & Ergonomic \\
\hline $\mathrm{K}_{3}$ & Elegant \\
\hline $\mathrm{K}_{4}$ & Innovative \\
\hline $\mathrm{K}_{5}$ & Feminine \\
\hline $\mathrm{K}_{6}$ & Organic \\
\hline
\end{tabular}

Table 3. Break up of desired coffee mug into items.

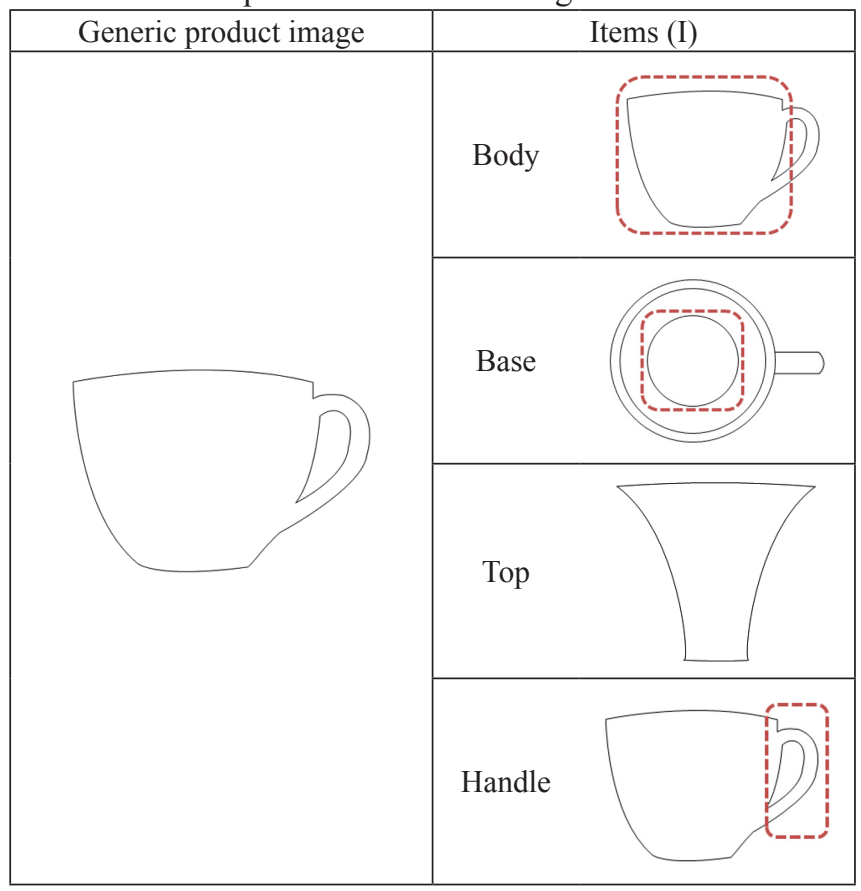


Table 4. Categorization of desired coffee mug items.

\begin{tabular}{|c|c|c|c|c|}
\hline ITEMS (I) & \multicolumn{4}{|c|}{ CATEGORIES (c) } \\
\hline \multirow[b]{2}{*}{ 1. Body } & 1. Figure I $\left(\mathrm{c}_{11}\right)$ & 2. Figure II $\left(c_{12}\right)$ & 3. Figure III $\left(c_{13}\right)$ & 4. Figure IV $\left(c_{14}\right)$ \\
\hline & & & & \\
\hline 2. Base & 1. Figure I $\left(\mathrm{c}_{21}\right)$ & 2. Figure II $\left(\mathrm{c}_{22}\right)$ & & \\
\hline 3. Тор & 1. Figure $I\left(c_{31}\right)$ & 2. Figure II $\left(\mathrm{c}_{32}\right)$ & & \\
\hline 4. Handle & 1. Figure $\mathrm{I}\left(\mathrm{c}_{41}\right)$ & 2. Figure II $\left(\mathrm{c}_{42}\right)$ & 3. Figure III $\left(\mathrm{c}_{43}\right)$ & \\
\hline
\end{tabular}

Table 5. Configurations of the selected coffee mugs.

\begin{tabular}{|c|c|c|c|c|}
\hline \multirow{2}{*}{ Products } & \multicolumn{4}{|c|}{ Product categories by item type } \\
\cline { 2 - 5 } & Body & Base & Top & Handle \\
\hline $\mathrm{P}_{1}$ & 1 & 1 & 2 & 2 \\
\hline $\mathrm{P}_{2}$ & 1 & 1 & 2 & 3 \\
\hline $\mathrm{P}_{3}$ & 1 & 2 & 1 & 1 \\
\hline $\mathrm{P}_{4}$ & 1 & 2 & 1 & 3 \\
\hline $\mathrm{P}_{5}$ & 2 & 1 & 1 & 1 \\
\hline $\mathrm{P}_{6}$ & 2 & 1 & 1 & 2 \\
\hline $\mathrm{P}_{7}$ & 2 & 2 & 1 & 1 \\
\hline $\mathrm{P}_{8}$ & 2 & 2 & 1 & 2 \\
\hline $\mathrm{P}_{9}$ & 2 & 2 & 2 & 3 \\
\hline $\mathrm{P}_{10}$ & 3 & 1 & 2 & 2 \\
\hline $\mathrm{P}_{11}$ & 3 & 1 & 2 & 3 \\
\hline $\mathrm{P}_{12}$ & 3 & 2 & 1 & 1 \\
\hline $\mathrm{P}_{13}$ & 3 & 2 & 2 & 3 \\
\hline $\mathrm{P}_{14}$ & 4 & 1 & 1 & 1 \\
\hline $\mathrm{P}_{15}$ & 4 & 1 & 2 & 2 \\
\hline $\mathrm{P}_{16}$ & 4 & 2 & 2 & 1 \\
\hline $\mathrm{P}_{17}$ & 4 & 2 & 2 & 2 \\
\hline $\mathrm{P}_{18}$ & 4 & 2 & 1 & 3 \\
\hline $\mathrm{P}_{19}$ & 3 & 1 & 1 & 3 \\
\hline $\mathrm{P}_{20}$ & 3 & 2 & 1 & 3 \\
\hline $\mathrm{P}_{21}$ & 3 & 2 & 2 & 1 \\
\hline $\mathrm{P}_{22}$ & 2 & 2 & 2 & 1 \\
\hline $\mathrm{P}_{23}$ & 1 & 1 & 1 & 2 \\
\hline $\mathrm{P}_{24}$ & 1 & 1 & 2 & 2 \\
\hline $\mathrm{P}_{25}$ & 1 & 2 & 1 & 3 \\
\hline & & & & \\
\hline & 2 & 2 & 1 & 2 \\
\hline
\end{tabular}

Phase 5. In this phase, the values of the relative degree of importance are attributed to the Kansei words, $\mathrm{K}_{1}$ to $\mathrm{K}_{6}$, by the participants, $\mathrm{C}_{1}$ to $\mathrm{C}_{10}$. These values are shown in Table 7.

Phase 6. In order to obtain the degree of contribution of the product characteristics, first, the average values of the consumer assessments are determined, $\mathrm{C}_{1}$ to $\mathrm{C}_{10}$, for each products-synthesis, $\mathrm{P}_{1}$ to $\mathrm{P}_{25}$, in relation to each Kansei word, $\mathrm{K}_{1}$ to $\mathrm{K}_{6}$, resulting in the values shown in Table 8 .

Next, the characteristics of the products-synthesis are translated in terms of a binary numeric representation, in which the presence of a given characteristic is symbolized by the number " 1 ," while its absence is symbolized by " 0 ". The binary numeric representation for the coffee mug configurations presented in Table 5 is given Table 9.

In order to determine the contribution scores of each category for the coffee mug product, the R code developed by Prof. Shigenobu Aoki of the Faculty of Social and Information Studies at Gunma University in Japan was used. This code was presented and ascertained by Nagamachi (2011). The result of the adjustment by using least squares is presented in Table 10.

Phase 7. In order to obtain the weight coefficients, the assessment presented in Table 7 must be converted to TFNs. Subsequently, the average relative degrees of importance of Kansei words are determined by using the collected values and their corresponding TFNs. In order to compare the 
Table 6. Excerpt of the coffee mug assessment with respect to the words "pleasant aesthetics" and "ergonomic".

\begin{tabular}{|c|c|c|c|c|c|c|c|c|c|c|c|c|c|c|c|c|c|c|c|c|}
\hline & \multicolumn{10}{|c|}{$\mathrm{K}_{1}$} & \multicolumn{10}{|c|}{$\mathrm{K}_{2}$} \\
\hline & $\mathrm{C}_{1}$ & $\mathrm{C}_{2}$ & $\mathrm{C}_{3}$ & $\mathrm{C}_{4}$ & $\mathrm{C}_{5}$ & $\mathrm{C}_{6}$ & $\mathrm{C}_{7}$ & $\mathrm{C}_{8}$ & $\mathrm{C}_{9}$ & $\mathrm{C}_{10}$ & $\mathrm{C}_{1}$ & $\mathrm{C}_{2}$ & $\mathrm{C}_{3}$ & $\mathrm{C}_{4}$ & $\mathrm{C}_{5}$ & $\mathrm{C}_{6}$ & $\mathrm{C}_{7}$ & $\mathrm{C}_{8}$ & $\mathrm{C}_{9}$ & $\mathrm{C}_{10}$ \\
\hline $\mathrm{P}_{1}$ & 5 & 7 & 7 & 7 & 8 & 7 & 3 & 7 & 7 & 7 & 8 & 2 & 4 & 7 & 1 & 7 & 7 & 1 & 7 & 7 \\
\hline $\mathrm{P}_{2}$ & 4 & 8 & 8 & 5 & 7 & 8 & 5 & 8 & 8 & 8 & 5 & 3 & 8 & 8 & 2 & 8 & 8 & 4 & 4 & 8 \\
\hline $\mathrm{P}_{3}$ & 8 & 9 & 5 & 6 & 7 & 4 & 4 & 5 & 5 & 5 & 4 & 5 & 7 & 5 & 5 & 5 & 9 & 7 & 4 & 4 \\
\hline $\mathrm{P}_{4}$ & 9 & 5 & 2 & 3 & 4 & 5 & 8 & 5 & 2 & 4 & 4 & 4 & 5 & 4 & 4 & 5 & 5 & 8 & 5 & 5 \\
\hline $\mathrm{P}_{5}$ & 6 & 4 & 1 & 2 & 4 & 2 & 8 & 5 & 4 & 1 & 5 & 1 & 1 & 1 & 4 & 2 & 6 & 9 & 5 & 1 \\
\hline $\mathrm{P}_{6}$ & 4 & 1 & 4 & 1 & 5 & 1 & 8 & 2 & 1 & 5 & 6 & 4 & 1 & 2 & 4 & 1 & 2 & 6 & 6 & 2 \\
\hline $\mathrm{P}_{7}$ & 7 & 2 & 5 & 4 & 1 & 2 & 9 & 4 & 2 & 5 & 9 & 1 & 1 & 2 & 2 & 1 & 1 & 3 & 5 & 2 \\
\hline $\mathrm{P}_{8}$ & 8 & 3 & 6 & 8 & 2 & 1 & 6 & 4 & 1 & 5 & 8 & 2 & 4 & 2 & 3 & 5 & 4 & 3 & 4 & 1 \\
\hline $\mathrm{P}_{9}$ & 9 & 6 & 3 & 9 & 1 & 4 & 4 & 1 & 2 & 5 & 7 & 5 & 5 & 5 & 3 & 5 & 7 & 2 & 7 & 4 \\
\hline$P_{10}$ & 7 & 4 & 2 & 5 & 2 & 7 & 7 & 1 & 4 & 7 & 4 & 4 & 6 & 4 & 6 & 5 & 7 & 1 & 8 & 7 \\
\hline $\mathrm{P}_{11}$ & 8 & 5 & 8 & 4 & 1 & 8 & 8 & 5 & 5 & 4 & 4 & 7 & 9 & 5 & 5 & 4 & 7 & 4 & 8 & 7 \\
\hline$P_{12}$ & 2 & 6 & 9 & 4 & 4 & 5 & 9 & 6 & 6 & 1 & 1 & 4 & 8 & 5 & 4 & 7 & 8 & 5 & 5 & 8 \\
\hline$P_{13}$ & 5 & 3 & 9 & 1 & 5 & 4 & 6 & 8 & 3 & 1 & 5 & 5 & 7 & 5 & 5 & 7 & 9 & 6 & 8 & 5 \\
\hline $\mathrm{P}_{14}$ & 6 & 5 & 7 & 2 & 7 & 2 & 5 & 7 & 2 & 3 & 7 & 6 & 8 & 4 & 5 & 5 & 6 & 5 & 7 & 9 \\
\hline$P_{15}$ & 1 & 4 & 4 & 5 & 8 & 1 & 4 & 5 & 4 & 6 & 8 & 9 & 9 & 4 & 6 & 6 & 5 & 7 & 4 & 9 \\
\hline$P_{16}$ & 7 & 7 & 4 & 5 & 7 & 4 & 7 & 2 & 7 & 5 & 5 & 8 & 5 & 2 & 6 & 9 & 4 & 8 & 5 & 6 \\
\hline$P_{17}$ & 4 & 8 & 1 & 5 & 7 & 7 & 8 & 1 & 8 & 4 & 6 & 7 & 4 & 2 & 9 & 8 & 7 & 9 & 8 & 4 \\
\hline $\mathrm{P}_{18}$ & 5 & 9 & 5 & 8 & 7 & 4 & 6 & 4 & 9 & 9 & 9 & 4 & 1 & 1 & 8 & 7 & 8 & 9 & 7 & 5 \\
\hline $\mathrm{P}_{19}$ & 6 & 6 & 6 & 7 & 7 & 7 & 5 & 5 & 6 & 6 & 8 & 1 & 5 & 5 & 7 & 4 & 9 & 8 & 4 & 5 \\
\hline $\mathrm{P}_{20}$ & 1 & 5 & 3 & 1 & 9 & 7 & 4 & 7 & 6 & 3 & 7 & 4 & 4 & 6 & 4 & 7 & 9 & 7 & 5 & 6 \\
\hline $\mathrm{P}_{21}$ & 4 & 2 & 2 & 1 & 5 & 7 & 7 & 8 & 5 & 3 & 4 & 5 & 7 & 6 & 1 & 8 & 9 & 4 & 7 & 9 \\
\hline $\mathrm{P}_{22}$ & 7 & 2 & 5 & 8 & 6 & 8 & 8 & 9 & 4 & 2 & 1 & 8 & 8 & 3 & 5 & 5 & 8 & 1 & 4 & 8 \\
\hline$P_{23}$ & 8 & 6 & 1 & 5 & 2 & 9 & 5 & 6 & 7 & 1 & 2 & 8 & 4 & 2 & 4 & 4 & 4 & 5 & 5 & 7 \\
\hline $\mathrm{P}_{24}$ & 2 & 3 & 4 & 3 & 1 & 6 & 2 & 5 & 8 & 4 & 2 & 9 & 5 & 1 & 8 & 4 & 5 & 6 & 4 & 7 \\
\hline$P_{25}$ & 3 & 1 & 4 & 3 & 4 & 3 & 2 & 4 & 8 & 5 & 5 & 7 & 4 & 4 & 8 & 4 & 6 & 8 & 5 & 8 \\
\hline
\end{tabular}

average relative degrees of importance, the standardization of these values is performed. For ordinary numbers, or crisp relative degrees of importance, the calculation of the average, exemplified for Kansei word $\mathrm{K}_{1}$, is, using the notation by Chan and $\mathrm{Wu}(2005)$, given by

$$
\begin{aligned}
& \mathrm{g}_{\mathrm{c} 1}=\frac{\sum_{i=1}^{10}\left(\mathrm{~g}_{1 \mathrm{i}} / 10\right)=\left(\begin{array}{l}
\mathrm{g}_{11}+\mathrm{g}_{12}+\mathrm{g}_{13}+ \\
\mathrm{g}_{14}+\mathrm{g}_{15}+\mathrm{g}_{16}+ \\
\mathrm{g}_{17}+\mathrm{g}_{18}+\mathrm{g}_{19}+\mathrm{g}_{110}
\end{array}\right)}{10}= \\
& \frac{(9+4+5+8+4+8+9+2+7+4)}{10}=6
\end{aligned}
$$

where $g_{1 i}$ is the relative degree of importance of the Kansei word $\mathrm{K}_{1}$ attributed by consumer $\mathrm{i}$, represented in terms of a crisp notation.

For the corresponding TFNs, the average is calculated using the operational properties of scalar multiplication and addition discussed in Section 3.

$$
\begin{aligned}
& \left.\qquad \begin{array}{l}
{\left[\tilde{\mathrm{g}}_{11}\right]+\left[\tilde{\mathrm{g}}_{12}\right]+\left[\tilde{\mathrm{g}}_{13}\right]+} \\
{\left[\tilde{\mathrm{g}}_{14}\right]+\left[\tilde{\mathrm{g}}_{15}\right]+\left[\tilde{\mathrm{g}}_{16}\right]+} \\
{\left[\tilde{\mathrm{g}}_{17}\right]+\left[\tilde{\mathrm{g}}_{18}\right]+\left[\tilde{\mathrm{g}}_{19}\right]+\left[\tilde{\mathrm{g}}_{1 \mathrm{i}}\right]}
\end{array}\right] \\
& \tilde{\mathrm{g}}_{\mathrm{f} 1}=\sum_{\mathrm{i}=1}^{10} \tilde{\mathrm{g}}_{1 \mathrm{i}}=\frac{10}{[[8,9,9]+[3,4,5]+[4,5,6]+} \\
& {\left[\begin{array}{l}
{[7,8,9]+[3,4,5]+[7,8,9]+} \\
{[8,9,9]+[1,2,3]+[6,7,8]+[3,4,5]}
\end{array}=[11,6,6.8]\right.}
\end{aligned}
$$

where $\tilde{\mathrm{g}}_{1 \mathrm{i}}$ is the relative degree of importance of the Kansei word $\mathrm{K}_{1}$ attributed by consumer $\mathrm{i}$, represented in terms of TFNs.

Considering linguistic variables $\mathrm{K}_{1}$ to $\mathrm{K}_{6}$, we determine the values given in Table 11 .

The crisp and fuzzy average values presented in Table 11 are then standardized so that the maximum value is in units. In particular, each element of the crisp average 
Table 7. Degree of importance values attributed to Kansei words by hypothetical consumers.

\begin{tabular}{|c|c|c|c|c|c|c|c|c|c|c|}
\hline & $\mathrm{C}_{1}$ & $\mathrm{C}_{2}$ & $\mathrm{C}_{3}$ & $\mathrm{C}_{4}$ & $\mathrm{C}_{5}$ & $\mathrm{C}_{6}$ & $\mathrm{C}_{7}$ & $\mathrm{C}_{8}$ & $\mathrm{C}_{9}$ & $\mathrm{C}_{10}$ \\
\hline $\mathrm{K}_{1}$ & 9 & 4 & 5 & 8 & 4 & 8 & 9 & 2 & 7 & 4 \\
\hline $\mathrm{K}_{2}$ & 7 & 7 & 4 & 9 & 5 & 8 & 9 & 3 & 4 & 8 \\
\hline $\mathrm{K}_{3}$ & 5 & 5 & 5 & 7 & 4 & 7 & 9 & 1 & 4 & 8 \\
\hline $\mathrm{K}_{4}$ & 8 & 9 & 5 & 9 & 6 & 7 & 5 & 1 & 6 & 6 \\
\hline $\mathrm{K}_{5}$ & 4 & 9 & 2 & 6 & 6 & 9 & 4 & 4 & 8 & 7 \\
\hline $\mathrm{K}_{6}$ & 7 & 6 & 4 & 4 & 3 & 6 & 7 & 3 & 8 & 7 \\
\hline
\end{tabular}

Table 8. Average values of the scores attributed to the products with respect to adherence to Kansei words.

\begin{tabular}{|c|c|c|c|c|c|c|}
\hline & $\mathrm{K}_{1}$ & $\mathrm{~K}_{2}$ & $\mathrm{~K}_{3}$ & $\mathrm{~K}_{4}$ & $\mathrm{~K}_{5}$ & $\mathrm{~K}_{6}$ \\
\hline$P_{1}$ & 6.50 & 5.10 & 5.00 & 6.10 & 4.70 & 5.00 \\
\hline $\mathrm{P}_{2}$ & 6.90 & 5.80 & 5.60 & 6.40 & 4.60 & 4.60 \\
\hline $\mathrm{P}_{3}$ & 5.80 & 5.50 & 6.20 & 6.10 & 5.20 & 3.00 \\
\hline $\mathrm{P}_{4}$ & 4.70 & 4.90 & 5.60 & 5.50 & 5.90 & 4.10 \\
\hline $\mathrm{P}_{5}$ & 3.70 & 3.50 & 4.20 & 4.60 & 6.50 & 4.30 \\
\hline $\mathrm{P}_{6}$ & 3.20 & 3.40 & 4.00 & 4.10 & 5.70 & 6.40 \\
\hline $\mathrm{P}_{7}$ & 4.10 & 2.70 & 3.60 & 4.50 & 5.20 & 7.50 \\
\hline $\mathrm{P}_{8}$ & 4.40 & 3.60 & 4.00 & 4.90 & 6.00 & 6.60 \\
\hline $\mathrm{P}_{9}$ & 4.40 & 5.00 & 4.80 & 5.40 & 4.80 & 5.40 \\
\hline $\mathrm{P}_{10}$ & 4.60 & 5.20 & 5.30 & 5.90 & 6.00 & 4.80 \\
\hline $\mathrm{P}_{11}$ & 5.60 & 6.00 & 5.70 & 5.30 & 5.30 & 5.70 \\
\hline $\mathrm{P}_{12}$ & 5.20 & 5.50 & 6.20 & 5.00 & 6.20 & 5.80 \\
\hline $\mathrm{P}_{13}$ & 4.50 & 6.20 & 5.50 & 4.80 & 7.00 & 4.00 \\
\hline $\mathrm{P}_{14}$ & 4.60 & 6.20 & 4.80 & 5.10 & 5.90 & 4.50 \\
\hline $\mathrm{P}_{15}$ & 4.20 & 6.70 & 5.60 & 6.20 & 5.50 & 5.00 \\
\hline $\mathrm{P}_{16}$ & 5.50 & 5.80 & 5.30 & 6.80 & 5.50 & 5.80 \\
\hline $\mathrm{P}_{17}$ & 5.30 & 6.40 & 5.50 & 7.50 & 5.30 & 5.50 \\
\hline $\mathrm{P}_{18}$ & 6.60 & 5.90 & 5.50 & 6.70 & 4.40 & 5.50 \\
\hline $\mathrm{P}_{19}$ & 6.10 & 5.60 & 6.40 & 5.80 & 5.20 & 5.50 \\
\hline $\mathrm{P}_{20}$ & 4.60 & 5.90 & 5.30 & 5.50 & 6.00 & 4.90 \\
\hline $\mathrm{P}_{21}$ & 4.40 & 6.00 & 5.90 & 5.40 & 6.60 & 5.00 \\
\hline $\mathrm{P}_{22}$ & 5.90 & 5.10 & 4.70 & 6.30 & 5.60 & 5.30 \\
\hline $\mathrm{P}_{23}$ & 5.00 & 4.50 & 5.20 & 7.50 & 6.40 & 5.00 \\
\hline $\mathrm{P}_{24}$ & 3.80 & 5.10 & 4.70 & 6.20 & 5.80 & 5.10 \\
\hline $\mathrm{P}_{25}$ & 3.70 & 5.90 & 3.60 & 5.90 & 5.70 & 4.80 \\
\hline
\end{tabular}

value set is divided by the relatively high threshold. In the standardization of the TFN set, each value in the ternium is divided by the relatively high threshold of points that characterize the TFNs. Thus, the values provided in Table 12 are calculated as follows:

In this example, each point of the TFNs was compared with the associated crisp value by opting for the maximum values, which were determined as the weight coefficients for Kansei words given in Table 13.

As one can see in Table 13, the weight coefficients relative to Kansei words can be ordered as follows:

$$
\mathrm{W}_{2} \succ \mathrm{W}_{4} \succ \mathrm{W}_{1} \succ \mathrm{W}_{5} \mathrm{~W}_{6} \succ \mathrm{W}_{3}
$$

where the symbol $\succ$. presents the expression "more important than". Consequently, the Kansei word "ergonomic" was considered the most important, while the word "elegant" was considered the least important in the set of the words for the desired coffee mug.

Phase 8. In order to determine product configurations that maximize the use of characteristics with relatively high scores, a genetic algorithm, $\mathbf{G}$, is used for obtaining the chromosome matrix. $\mathbf{G}$ values provided for each GA creation are assessed through the assessment function given by Equation 6, and from there, the products with relatively high scores are determined in terms of the binary notation. 
For the coffee mug example, imagine that the first creation of chromosomes is analyzed, as presented in Table 9. The assessment of each chromosome in this case, by considering the values of the contribution score matrix and the weight coefficients of Kansei words calculated in previous phases, is established through Equation 7, as exemplified below for products-synthesis $\mathrm{P}_{1}$ :

$$
\mathrm{F}_{\mathrm{P}_{1}}=\sum_{\mathrm{i}=1}^{6} \mathrm{w}_{\mathrm{i}} \sum_{\mathrm{s}=1}^{4} \sum_{\mathrm{j}=1}^{\mathrm{k}_{\mathrm{s}}} \mathrm{G}_{1 \mathrm{sj}} \mathrm{a}_{\mathrm{sji}}=0.4
$$

Table 9. Binary numerical representation of the determined coffee mug configurations.

\begin{tabular}{|c|c|c|c|c|c|c|c|c|c|c|c|}
\hline & \multicolumn{4}{|c|}{ Body } & \multicolumn{2}{|c|}{ Base } & \multicolumn{2}{|c|}{ Top } & \multicolumn{3}{|c|}{ Handle } \\
\hline & $\mathrm{c}_{11}$ & $\mathrm{c}_{12}$ & $\mathrm{c}_{13}$ & $\mathrm{c}_{14}$ & $\mathrm{c}_{21}$ & $\mathrm{c}_{22}$ & $\mathrm{c}_{31}$ & $c_{32}$ & $\mathrm{c}_{41}$ & $\mathrm{c}_{42}$ & $\mathrm{c}_{43}$ \\
\hline $\mathrm{P}_{1}$ & 1 & 0 & 0 & 0 & 1 & 0 & 0 & 1 & 0 & 1 & 0 \\
\hline $\mathrm{P}_{2}$ & 1 & 0 & 0 & 0 & 1 & 0 & 0 & 1 & 0 & 0 & 1 \\
\hline $\mathrm{P}_{3}$ & 1 & 0 & 0 & 0 & 0 & 1 & 1 & 0 & 1 & 0 & 0 \\
\hline $\mathrm{P}_{4}$ & 1 & 0 & 0 & 0 & 0 & 1 & 1 & 0 & 0 & 0 & 1 \\
\hline $\mathrm{P}_{5}$ & 0 & 1 & 0 & 0 & 1 & 0 & 1 & 0 & 1 & 0 & 0 \\
\hline $\mathrm{P}_{6}$ & 0 & 1 & 0 & 0 & 1 & 0 & 1 & 0 & 0 & 1 & 0 \\
\hline $\mathrm{P}_{7}$ & 0 & 1 & 0 & 0 & 0 & 1 & 1 & 0 & 1 & 0 & 0 \\
\hline $\mathrm{P}_{8}$ & 0 & 1 & 0 & 0 & 0 & 1 & 1 & 0 & 0 & 1 & 0 \\
\hline $\mathrm{P}_{9}$ & 0 & 1 & 0 & 0 & 0 & 1 & 0 & 1 & 0 & 0 & 1 \\
\hline $\mathrm{P}_{10}$ & 0 & 0 & 1 & 0 & 1 & 0 & 0 & 1 & 0 & 1 & 0 \\
\hline$P_{11}$ & 0 & 0 & 1 & 0 & 1 & 0 & 0 & 1 & 0 & 0 & 1 \\
\hline $\mathrm{P}_{12}$ & 0 & 0 & 1 & 0 & 0 & 1 & 1 & 0 & 1 & 0 & 0 \\
\hline $\mathrm{P}_{13}$ & 0 & 0 & 1 & 0 & 0 & 1 & 0 & 1 & 0 & 0 & 1 \\
\hline $\mathrm{P}_{14}$ & 0 & 0 & 0 & 1 & 1 & 0 & 1 & 0 & 1 & 0 & 0 \\
\hline $\mathrm{P}_{15}$ & 0 & 0 & 0 & 1 & 1 & 0 & 0 & 1 & 0 & 1 & 0 \\
\hline $\mathrm{P}_{16}$ & 0 & 0 & 0 & 1 & 0 & 1 & 0 & 1 & 1 & 0 & 0 \\
\hline $\mathrm{P}_{17}$ & 0 & 0 & 0 & 1 & 0 & 1 & 0 & 1 & 0 & 1 & 0 \\
\hline $\mathrm{P}_{18}$ & 0 & 0 & 0 & 1 & 0 & 1 & 1 & 0 & 0 & 0 & 1 \\
\hline$P_{19}$ & 0 & 0 & 1 & 0 & 1 & 0 & 1 & 0 & 0 & 0 & 1 \\
\hline $\mathrm{P}_{20}$ & 0 & 0 & 1 & 0 & 0 & 1 & 1 & 0 & 0 & 0 & 1 \\
\hline $\mathrm{P}_{21}$ & 0 & 0 & 1 & 0 & 0 & 1 & 0 & 1 & 1 & 0 & 0 \\
\hline $\mathrm{P}_{22}$ & 0 & 1 & 0 & 0 & 0 & 1 & 0 & 1 & 1 & 0 & 0 \\
\hline $\mathrm{P}_{23}$ & 1 & 0 & 0 & 0 & 1 & 0 & 1 & 0 & 0 & 1 & 0 \\
\hline $\mathrm{P}_{24}$ & 1 & 0 & 0 & 0 & 1 & 0 & 0 & 1 & 0 & 1 & 0 \\
\hline $\mathrm{P}_{25}$ & 1 & 0 & 0 & 0 & 0 & 1 & 1 & 0 & 0 & 0 & 1 \\
\hline
\end{tabular}

Table 10. Contribution scores of each category for the desired coffee mug.

\begin{tabular}{|c|c|c|c|c|c|c|}
\hline & $\mathrm{K}_{1}$ & $\mathrm{~K}_{2}$ & $\mathrm{~K}_{3}$ & $\mathrm{~K}_{4}$ & $\mathrm{~K}_{5}$ & $\mathrm{~K}_{6}$ \\
\hline $\mathrm{c}_{11}$ & 0.32913 & 0.05156 & 0.04996 & 0.52113 & -0.12742 & -0.71974 \\
\hline $\mathrm{c}_{12}$ & -0.53860 & -1.22835 & -0.90567 & -0.73468 & -0.16406 & 0.73083 \\
\hline $\mathrm{c}_{13}$ & -0.10658 & 0.33407 & 0.58726 & -0.34885 & 0.54786 & 0.03563 \\
\hline $\mathrm{c}_{14}$ & 0.33475 & 0.93414 & 0.19470 & 0.64042 & -0.39174 & 0.08075 \\
\hline $\mathrm{c}_{21}$ & 0.06251 & -0.08033 & 0.00422 & -0.17366 & -0.08715 & -0.10715 \\
\hline $\mathrm{c}_{22}$ & -0.04911 & 0.06312 & -0.00332 & 0.13645 & 0.06848 & 0.08419 \\
\hline $\mathrm{c}_{31}$ & -0.19916 & -0.30359 & -0.08413 & -0.20241 & 0.10852 & 0.08173 \\
\hline $\mathrm{c}_{32}$ & 0.21576 & 0.32889 & 0.09114 & 0.21928 & -0.11756 & -0.08854 \\
\hline $\mathrm{c}_{41}$ & 0.13657 & -0.04621 & 0.14223 & -0.14217 & 0.18261 & -0.28142 \\
\hline $\mathrm{c}_{42}$ & -0.46090 & -0.29478 & -0.15765 & 0.21674 & 0.23428 & 0.40756 \\
\hline $\mathrm{c}_{43}$ & 0.28830 & 0.30310 & 0.01371 & -0.06628 & -0.37057 & -0.11212 \\
\hline
\end{tabular}


Table 11. Degrees of importance attributed to Kansei words by hypothetical consumers.

\begin{tabular}{|c|c|c|c|c|c|c|c|c|c|c|c|c|c|}
\hline \multirow{2}{*}{} & \multicolumn{2}{|c|}{$\mathrm{C}_{1}$} & \multicolumn{2}{c|}{$\mathrm{C}_{2}$} & \multicolumn{2}{c|}{$\mathrm{C}_{3}$} & \multicolumn{2}{c|}{$\mathrm{C}_{4}$} & $\ldots$ & \multicolumn{2}{|c|}{$\mathrm{C}_{10}$} & \multicolumn{2}{c|}{ Average values } \\
\cline { 2 - 9 } & crisp & Fuzzy & crisp & Fuzzy & crisp & fuzzy & crisp & fuzzy & $\ldots$ & crisp & Fuzzy & crisp & fuzzy \\
\hline $\mathrm{K}_{1}$ & 9 & $(8,9,9)$ & 4 & $(3,4,5)$ & 5 & $(4,5,6)$ & 8 & $(7,8,9)$ & $\ldots$ & 4 & $(3,4,5)$ & 6.00 & $(5.00,6.00,6.80)$ \\
\hline $\mathrm{K}_{2}$ & 7 & $(6,7,8)$ & 7 & $(6,7,8)$ & 4 & $(3,4,5)$ & 9 & $(8,9,9)$ & $\ldots$ & 8 & $(7,8,9)$ & 6.40 & $(5.40,6.40,7.20)$ \\
\hline $\mathrm{K}_{3}$ & 5 & $(4,5,6)$ & 5 & $(4,5,6)$ & 5 & $(4,5,6)$ & 7 & $(6,7,8)$ & $\ldots$ & 8 & $(7,8,9)$ & 5.50 & $(4.60,5.50,6.40)$ \\
\hline $\mathrm{K}_{4}$ & 8 & $(7,8,9)$ & 9 & $(8,9,9)$ & 5 & $(4,5,6)$ & 9 & $(8,9,9)$ & $\ldots$ & 6 & $(5,6,7)$ & 6.20 & $(5.40,6.30,7.10)$ \\
\hline $\mathrm{K}_{5}$ & 4 & $(3,4,5)$ & 9 & $(8,9,9)$ & 2 & $(1,2,3)$ & 6 & $(5,6,7)$ & $\ldots$ & 7 & $(6,7,8)$ & 5.90 & $(4.90,5.90,6.70)$ \\
\hline $\mathrm{K}_{6}$ & 7 & $(6,7,8)$ & 6 & $(5,6,7)$ & 4 & $(3,4,5)$ & 4 & $(3,4,5)$ & $\ldots$ & 7 & $(6,7,8)$ & 5.50 & $(4.50,5.50,6.50)$ \\
\hline
\end{tabular}

Table 12. Standardized values of average relative degrees of importance.

\begin{tabular}{|l|c|c|c|c|}
\hline & Crisp & \multicolumn{3}{|c|}{ TFNs } \\
\hline $\mathrm{W}_{1}$ & 0.9375 & 0.6944 & 0.8333 & 0.9444 \\
\hline $\mathrm{W}_{2}$ & 1.0000 & 0.7500 & 0.8889 & 1.0000 \\
\hline $\mathrm{W}_{3}$ & 0.8594 & 0.6389 & 0.7639 & 0.8889 \\
\hline $\mathrm{W}_{4}$ & 0.9688 & 0.7500 & 0.8750 & 0.9861 \\
\hline $\mathrm{W}_{5}$ & 0.9219 & 0.6806 & 0.8194 & 0.9306 \\
\hline $\mathrm{W}_{6}$ & 0.8594 & 0.6250 & 0.7639 & 0.9028 \\
\hline
\end{tabular}

Table 13. Weight coefficients of Kansei words.

\begin{tabular}{|c|c|}
\hline \multicolumn{2}{|c|}{ Weight coefficients } \\
\hline $\mathrm{W}_{1}$ & 0.9444 \\
\hline $\mathrm{W}_{2}$ & 1.0000 \\
\hline $\mathrm{W}_{3}$ & 0.8889 \\
\hline $\mathrm{W}_{4}$ & 0.9861 \\
\hline $\mathrm{W}_{5}$ & 0.9306 \\
\hline $\mathrm{W}_{6}$ & 0.9028 \\
\hline
\end{tabular}

After the assessment of each chromosome, the elements of a vector $\mathbf{f}$ are obtained and compared by establishing a ranking of product configurations. The assessment function values and the respective chromosome chains of the three configurations for the coffee mug with the highest assessment are given in Table 14.

In general, new chromosome creations are obtained by determining other entry data, such as the number of chromosomes created in each cycle, number of creations (cycles), crossover points, and the degree of elitism. The chromosomes obtained in each cycle are assessed using Equation 7, as exemplified for $\mathrm{P}_{1}$, and compared in order to obtain the optimal product configurations.

Phase 9. In order to decode the output data, at the end of the optimization cycles, the items and categories associated with each gene of the created chromosomes are identified.

The genes given in Table 14 are figurative representatives of the coffee mug items presented in Table 4 such that gene 1 represents the item "body," gene 2 represents the item "base," gene 3 represents the item "top," and gene
4 represents the item "handle". Moreover, knowing that the binary representation for each gene indicates the presence (1) or absence (0) of a given category, we can decode the chromosomes. For the three chromosomes with the relatively high assessment values, the configurations are given in Table 15.

The configurations of coffee mugs presented in Table 15 can be more associated with the consumer and user impressions detailed by the Kansei words "ergonomic" and "innovative", providing the project team with a schematic synthesis of the Kansei of these consumers, which should assist in the new product project.

\section{Concluding remarks}

The literature regarding Kansei engineering presents different proposals to structure Kansei engineering systems using varied compositions of mathematical, statistical, and heuristic methods. The objective of this work was to propound a Kansei engineering system using an unexplored composition of methods, i.e., quantification theory type I, triangular fuzzy numbers, and genetic algorithms to support the involvement of consumers in the project.

The proposal preserves the benefits present in other Kansei engineering systems refered in the literature, providing a product assessment estimates based on prior information obtained from consumers, i.e., the inference of crowd impressions for new product concepts, concerning the use of quantification theory type I. Contributes to a better treatment of the inaccuracies and vagueness existing in consumer impressions through the use of triangular fuzzy numbers to evaluate the weights. The fuzzy logic is recognized for its ability to handling with qualitative assessments, considering the ambiguity aspect. The use of triangular fuzzy numbers in the treatment of the weight coefficients of Kansei responses has not been reported in other papers in this field. The proposal also uses the genetic algorithms artifice to obtain a diversity of product concepts. There are proposals for Kansei systems using genetic algorithm, but in order to optimize and get the final solution design. The proposal in this paper innovates by proposing the use of genetic algorithm to generate populations 
Table 14. Chromosome chains of the coffee mug configurations with the highest assessments.

\begin{tabular}{|l|l|l|l|l|l|l|l|l|l|l|l|l|l|}
\hline & \multicolumn{9}{|c|}{ Gene 1 } & \multicolumn{3}{c|}{ Gene 2 } & \multicolumn{3}{c|}{ Gene 3 } & \multicolumn{3}{|c|}{ Gene 4 } & Assessment \\
\hline Chromosome 16 & 0 & 0 & 0 & 1 & 0 & 1 & 0 & 1 & 1 & 0 & 0 & 14,197 \\
\hline Chromosome 17 & 0 & 0 & 0 & 1 & 0 & 1 & 0 & 1 & 0 & 1 & 0 & 11,900 \\
\hline Chromosome 13 & 0 & 0 & 1 & 0 & 0 & 1 & 0 & 1 & 0 & 0 & 1 & 11,219 \\
\hline
\end{tabular}

Table 15. Illustrative configuration of coffee mugs with relatively high assessment values.

\begin{tabular}{|c|c|c|c|c|}
\hline Gene & Items & Chromosome 16 & Chromosome 17 & Chromosome 13 \\
\hline 1 & Body & & & \\
\hline 2 & Base & $\square$ & $\supset$ & \\
\hline 3 & Top & & $\square$ & D \\
\hline 4 & Handle & & & \\
\hline
\end{tabular}

of solutions that concern to customer impressions. These populations of solutions are not seen as the solution of the project, but as source of ideas for the project team to generate final solutions, using their experience and aiming more innovative products.

Another important contribution of the paper is the use of an operacional and detailed approach to describe the procedure, with a step-by-step description for the use of this system (KES model). An example of the development of a simple product, a coffee mug, was presented. In parallel, the mathematical structure of the proposal is described. A detailed description of a simple example and the presentation of the mathematical modeling enables an understanding and generalization to other products. This facilitates the use by other researchers and business professionals, which can test and use the proposal for real cases of product development.

In this paper we do not check the use of the proposal in more complex products. We are conscious that a design of a coffee mug is a very simple case. Thus, how can we extend the application to real cases? As presented earlier, there are several Kansei engineering applications in real cases, and there are significant indications that our proposal is a feasible of Kansei engineering system, and consequently applicable in a design of products of high complexity, e.g. mobile phones, and cars. Considering that the proposal preserves the essential elements and phases of a Kansei engineering method, we don't see any impediments for its extention to more complex design cases. Therefore, we believed that it would be possible to apply in such cases. Obviously, this statement needs to be tested. The didactic and generic description is the first step, and the test in cases of more complexity is object for complementary researches, already in development by the research group. In practical applications will also be necessary the introduction of computational tools as $\mathrm{R}$ and MATLAB programs to implement the KES model proposal for complex products that, often, requires handling of innumerous data about product properties and customers' inputs.

The proposed Kansei engineering system is shown to be attainable, but some observations are important for the researcher who wishes to replicate these studies. First, is important to refer that the process of refinement of properties in the Phase 3 requires many exploration and research yet, and it isn't a problem exclusively of our work. It is an unresolved and criticized limitation discussed by the current literature in the area. It isn't our objetive in this paper to solve this problem. Second, It is interesting to 
consider that the dynamic and the context in which the data collection with potential consumers and users, especially in Phases 4 and 5, as well as the temporal variability in the opinion of the participants, may turn the Kansei engineering system into a relatively unstable "machine", with results that need to be validated by a relevant and coherent sample of the participants over time and by using certain means to request information that render relatively reliable and stable results. The third observation refers to the determination of weight coefficients in Phase 7. The inclusion of these coefficients in the assessment function inserted in the heuristic of the genetic algorithm provides the classification of the order of importance for Kansei words that influences and restricts the final configuration results of the products created, providing relatively high scores to the configurations that evoke, in the participants, the impressions indicated by Kansei words considered more important by these consumers and/or users.

The proposed Kansei engineering system can support the product project team in the steps involving the creation of ideas and concepts frequently performed at the beginning of the product development process for new products. As discussed at the beginning of this paper, the involvement of the consumer is important in the development of new products but is difficult to operationalize. The use of virtual platforms to support consumer involvement has been suggested in the literature as a way to facilitate the development of highly innovative product with the support of users and consumers. The proposed Kansei engineering system in this context would work as a platform for enabling the involvement of the consumers of manufactured products, classified as consumer goods, produced on a large scale during the product development process.

This type of system would have as a differential factor for the creation of product concepts according to consumer impressions. The project team can use these concepts as entry data and then create solutions that are innovative but respect such impressions. It would be a relatively objective way to assist the project team in easily comprehending consumer impressions with respect to product characteristics, as it aids the development of relatively innovative products. Finally, it is important to refer that our intention is not to resolve all problems existing in the area of Kansei engineering, but to provide a basal contribution, i.e., a KES model with many benefits relating its specific composition of methods, to support the new product development. Furthermore, the paper presents the KES model in an easy way, aiming a replication with extention by the project team in many cases of product development.

\section{References}

BARNES, C.; LILFORD, S. P. Decision support for the design of affective products. Journal of Engineering Design, v. 20, n. 5, p. 477-492, 2009. http://dx.doi. org/10.1080/09544820902875041.
BONNER, J. V. H.; PORTER, J. M. Envisioning future needs: from pragmatics to pleasure. In: GREEN, W. S.; JORDAN, P. W. (Eds.). Pleasure with products: beyond usability. London: Taylor \& Francis, 2002.

CHAN, L. K.; KAO, H. P.; WU, M. L. Rating the importance of customer needs in quality function deployment by fuzzy and entropy methods. International Journal of Production Research, v. 37, n. 11, p. 2499-2518, 1999. http://dx.doi. org/10.1080/002075499190635.

CHAN, L.; WU, M. A systematic approach to quality function deployment with a full illustrative example. International Journal of Management Sciences, v. 33, p. 119-139, 2005.

CHEN, C.; CHUANG, M. Integrating the Kano model into a robust design approach to enhance customer satisfaction with product design. International Journal of Production Economics, v. 114, n. 2, p. 667-681, 2008. http://dx.doi. org/10.1016/j.jpe.2008.02.015.

DELIN, J. et al. Linguistic support for concept selection decisions. Artificial Intelligence for Engineering Design, Analysis and Manufacturing, v. 21, n. 1, p. 123-135, 2007.

DUBOIS, D.; PRADE, H. Fuzzy sets and systems: theory and applications. New York: Academic, 1980.

GEN, M.; CHENG, R. Genetic algorithms and engineering design. New York: Wiley, 1997.

HAYASHI, C. Method of quantification. Tokio: Toyokeizai, 1974.

HAYASHI, C. On the prediction of phenomena from qualitative data and the quantification of qualitative data the mathematic-statistical point of view. Annals of the Institute of Statistical Mathematics, v. 3, n. 1, p. 69-98, 1952.

HAYASHI, C. Multidimensional quantification, II. Proceedings of the Japan Academy, v. 30, n. 3, p. 165-169, 1954. http:// dx.doi.org/10.3792/pja/1195526144.

HOLLAND, J. H. Adaptation in natural and artificial systems: an introductory analysis with applications to biology, control, and artificial intelligence. Massachusetts: MIT Press, 1992.

HSIAO, S.; CHIU, F.; LU, S. Product-form design model based on genetic algorithms. International Journal of Industrial Ergonomics, v. 40, n. 2, p. 237-246, 2010. http://dx.doi. org/10.1016/j.ergon.2010.01.009.

HUYNH, V.; YAN, H.; NAKAMORI, Y. A target-based decision-making approach to consumer-oriented evaluation model for Japanese traditional crafts. IEEE Transactions on Engineering Management, v. 57, n. 4, p. 575-588, 2010. http://dx.doi.org/10.1109/TEM.2009.2025494.

ISHIHARA, S. Psychophysiological methods. In: NAGAMACHI, M. (Ed.). Kansei/affective engineering. New York: CRC Press, 2011. 
ISHIHARA, S.; NAGAMACHI, M.; ISHIHARA, K. Neural networks Kansei expert system for wrist watch design. Advances in Human Factors/Ergonomics, v. 20, p. 167$172,1995$.

JOHNSON, R. A.; WICHERN, D. W. Applied multivariate statistical analysis. 6th ed. Upper Saddle River: Pearson Prentice-Hall, 2007.

LAI, H. et al. User-oriented design for the optimal combination on product design. International Journal of Production Economics, v. 100, n. 1, p. 253-267, 2006. http://dx.doi. org/10.1016/j.ijpe.2004.11.005.

LAI, H.; CHANG, Y.; CHANG, H. A robust design approach for enhancing the feeling quality of a product: a car profile case study. International Journal of Industrial Ergonomics, v. 35, n. 3, p. 445-460, 2005. http://dx.doi. org/10.1016/j.ergon.2004.10.008.

LETTL, C. User involvement competence for radical innovation. Journal of Engineering and Technology Management, v. 24, n. 1, p. 53-75, 2007. http://dx.doi. org/10.1016/j.jengtecman.2007.01.004.

LIN, Y.; LAI, H.; YEH, C. Consumer-oriented product form design based on fuzzy logic: a case study of mobile phones. International Journal of Industrial Ergonomics, v. 37, n. 4, p. 531-543, 2007.

NAGAMACHI, M. Kansei engineering: a new ergonomic consumer-oriented technology for product development. International Journal of Industrial Ergonomics, v. 15, n. 1, p. 3-11, 1995. http://dx.doi.org/10.1016/01698141(94)00052-5.

NAGAMACHI, M. Kansei engineering as a powerful consumer-oriented technology for product development. Applied Ergonomics, v. 33, n. 3, p. 289-294, 2002. http://dx.doi.org/10.1016/S0003-6870(02)00019-4. PMid:12164511.

NAGAMACHI, M. Kansei engineering. In: STANTON, N. et al. (Ed.). Handbook of human factors and ergonomics methods. London: CRC Press, 2004.

NAGAMACHI, M. Perspectives and the new trend of Kansei/ affective engineering. The TQM Journal, v. 20, n. 4, p. 290298, 2008. http://dx.doi.org/10.1108/17542730810881285.

NAGAMACHI, M. Statistical analysis for Kansei/affective engineering. In: NAGAMACHI, M. (Ed.). Kansei/ Affective Engineering. New York: CRC Press, 2011.

NAGAMACHI, M.; LOKMAN, A. M. Innovations of Kansei Engineering. New York: CRC Press, 2011.

OsGOOD, C. E.; SuCI, G. J.; TANNENBAUM, P. H. The measurement of meaning. Illinois: University of Illinois Press, 1957.
SCHÜTTE, S. Developing the space of product properties supporting kansei engineering procedure. Kansei Engineering International, v. 5, n. 4, p. 11-19, 2006. http://dx.doi.org/10.5057/kei.5.4_11.

SCHÜTTE, S. et al. Affective meaning: the Kansei engineering approach. In: SCHIFFERSTEIN, H. N. J.; HEKKERT, P. (Ed.). Product experience: a multidisciplinary approach. New York: Elsevier, 2008.

SCHÜTTE, S. Evaluation of the affective coherence of the exterior and interior of chocolate snacks. Food Quality and Preference, v. 29, n. 1, p. 16-24, 2013. http://dx.doi. org/10.1016/j.foodqual.2013.01.008.

SCHÜTTE, S. T. W. Designing feelings into products: integrating Kansei engineering methodology in product development. 2002. 97 f. Thesis. Department of Mechanical Engineering, Institute of Technology, Linköpings Universitet, Linköping, 2002.

SCHÜTTE, S. T. W. Engineering emotional values in product design: Kansei engineering in development. 2005. 106 f. Dissertation. Department of Mechanical Engineering, Institute of Technology, Linköpings Universitet, Linköping, 2005.

SCHÜTTE, S. T. W. et al. Concepts, methods and tools in Kansei engineering. Theoretical Issues in Ergonomics Science, v. 5, n. 3, p. 214-232, 2004. http://dx.doi.org/10.1 080/1463922021000049980.

SCHÜTTE, S.; EKLUND, J. Design of rocker switches for work-vehicles: an application of Kansei Engineering. Applied Ergonomics, v. 36, n. 5, p. 557-567, 2005. http:// dx.doi.org/10.1016/j.apergo.2005.02.002. PMid:15950167.

STAPPERS, P. J.; HARADA, A.; LEE, S. Design based on Kansei. In: GREEN, W. S.; JORDAN, P. W. (Ed.). Pleasure with products: beyond usability. London: Taylor \& Francis, 2002.

THOMKE, S.; VON HIPPEL, E. Innovators. Harvard Business Review, v. 80, n. 4, p. 74-81, 2002. PMid:12024760.

VON HIPPEL, E. Lead users: a source of novel product concepts. Management Science, v. 32, n. 7, p. 791-805, 1986. http://dx.doi.org/10.1287/mnsc.32.7.791.

YANG, S.; NAGAMACHI, M.; LEE, S. Rule-based inference model for the Kansei engineering system. International Journal of Industrial Ergonomics, v. 24, n. 5, p. 459-471, 1999. http://dx.doi.org/10.1016/S0169-8141(98)00040-7.

ZHAI, L.; KHOO, L.; ZHONG, Z. A rough set based decision support approach to improving consumer affective satisfaction in product design. International Journal of Industrial Ergonomics, v. 39, n. 2, p. 295-302, 2009. http:// dx.doi.org/10.1016/j.ergon.2008.11.003. 